\title{
COINCIDENCE STUDY OF DOUBLE ELECTRON EMISSION ASSOCIATED WITH K-SHELL PHOTOIONIZATION OF $\mathrm{C}_{60}$
}

\author{
Sanja Lj. Korica ${ }^{a}$, Axel Reinköster ${ }^{b}$, Uwe Becker ${ }^{c}$ \\ a University Union - Nikola Tesla, Faculty for Ecology and \\ Environmental Protection, Belgrade, Republic of Serbia + \\ Fritz-Haber-Institut, Department of Molecular Physics, \\ Berlin, Federal Republic of Germany, \\ e-mail: koricasanja@gmail.com, \\ ORCID iD: (i)http://orcid.org/0000-0002-7915-9430 \\ ${ }^{b}$ Fritz-Haber-Institut, Department of Molecular Physics, \\ Berlin, Federal Republic of Germany \\ ${ }^{c}$ Fritz-Haber-Institut, Department of Molecular Physics, \\ Berlin, Federal Republic of Germany
}

DOI: 10.5937/vojtehg66-16527; https://doi.org/10.5937/vojtehg66-16527

FIELD: Molecular Physics, Photoelectron-Photoion Spectroscopy ARTICLE TYPE: Original Scientific Paper ARTICLE LANGUAGE: English

\begin{abstract}
:
The (multiple) photoionization and subsequent fragmentation of the $C_{60}$ molecule was studied with the synchrotron radiation after removing electrons from the inner K-shell. Our intention was especially focused on the dynamics of the subsequent fragmentation. In addition to 'normal' (non-coincident) electron and ion time-of-flight spectroscopy, we investigated this topic with the help of an electron-electron-coincidence measurement. Our experiment shows that in these processes $\mathrm{C}^{q^{+}}{ }_{60}$ ions with charge states up to $3+$ and several smaller $C^{q^{+}}{ }_{60-2 m}$ fragments are formed. In addition, the broad peak besides the $C(1 \mathrm{~s})$ line, usually referred to as the 'plasmon' peak, has been observed.
\end{abstract}

Key words: molecular physics, photoelectron-photoion spectroscopy, plasmon excitation.

\section{Introduction}

Since the discovery of $\mathrm{C}_{60}$ molecule (Kroto et al, 1985, pp.162-163), (Krätschmer et al, 1990, pp.354-358) many studies were performed to investigate its fundamental properties. Due to its high symmetry, $\mathrm{C}_{60}$

ACKNOWLEDGMENT: The authors are indebted to the Deutsche Forschungsgemainschaft (DFG) and to the Bundesministerium für Bildung und Forschung (BMBF) for the financial support. 
represents an ideal cluster with many possible applications. Its properties are mainly driven by its unique molecular structure like a spherical shell (Kusmany et al, 1993), (Korica et al, 2005, pp.132031-132035). So far, only a little is known about the $\mathrm{C}_{60}$ fragmentation after K-shell ionization (Aksela et al, 1995, pp.2112-2115), (Karvonen et al, 1997, pp.34663472), (Leiro et al, 2003, pp.205-213). For the main fragmentation channel, the (successive) emission of neutral $\mathrm{C}_{2}$ has been proposed for a low charge state (Scheier et al, 1994, pp.77-93), although the emission of other neutral carbon atoms/small clusters is also present (Lykke, 1995, pp.1354-1357). Even triply charged fullerene ions appear to be rather stable (Bernard et al, 2003, pp.196-200). Highly charged $C_{60}$ ions often decay through fission processes leading to a multiply charged fullerene and at least one other charged carbon atom or cluster, or they undergo multi-fragmentation processes leading exclusively to small, charged and neutral carbon clusters (Reinköster et al, 2003, pp.263-267).

\section{Experiment}

The measurements were performed at the HASYLAB undulator beam line BW3 in Hamburg and at the BESSYII dipole beamline TGM4 in Berlin using monochromatized synchrotron radiation whose wavelength can be scanned with a resolution set to an appropriale value. Measurements of Ne/Ar-resonances were carried out to check the accuracy of the monochromator settings. The photon beam crosses an effusive beam of $\mathrm{C}_{60}$ molecules, provided by an oven heated to $500{ }^{\circ} \mathrm{C}$. Outgoing electrons are detected in time-of-flight (TOF) electron spectrometers at two different angles with respect to the electric vector of the ionizing radiation(Fig1.(a)). Appropriate voltages can be applied to the TOF-analysers to keep a constant resolution of the electron spectra for different photon energies. Some measurements were recorded in the coincidence mode. Additional fullerene ion data were accumulated using a multi-hit capable ion spectrometer with a pulsed electrical separation field (Fig.1(b)). The positively charged $\mathrm{C}_{60}$ ions or fragments are separated according to their mass-per-charge ratio by a pulsed field (pulse amplitude $=820 \mathrm{~V}$, duration $=10 \mu \mathrm{s}$, repetition rate $=12 \mathrm{kHz}$, rise time $<15 \mathrm{~ns}$, field length $=5 \mathrm{~mm}$ ). The ions are accelerated into a potential of $-2800 \mathrm{~V}$ (field length $=4 \mathrm{~mm}$ ) followed by a $200 \mathrm{~mm}$ long field-free drift tube. After passing the drift tube, the ions hit the detector surface which is held at a constant voltage of $-3300 \mathrm{~V}$. The distance from the drift tube to the detector is $5 \mathrm{~mm}$. The detector consists of a Z-stack of MCPs with an active diameter of $40 \mathrm{~mm}$. 


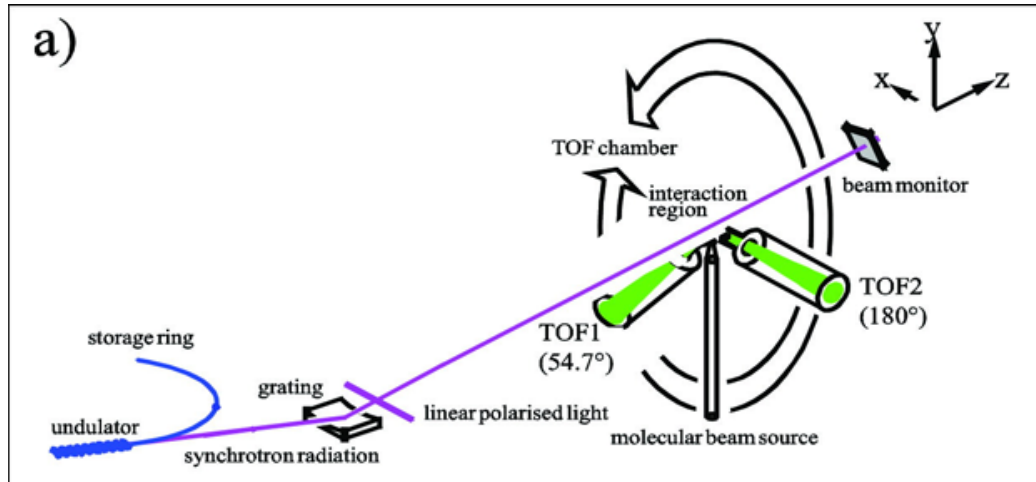

b)
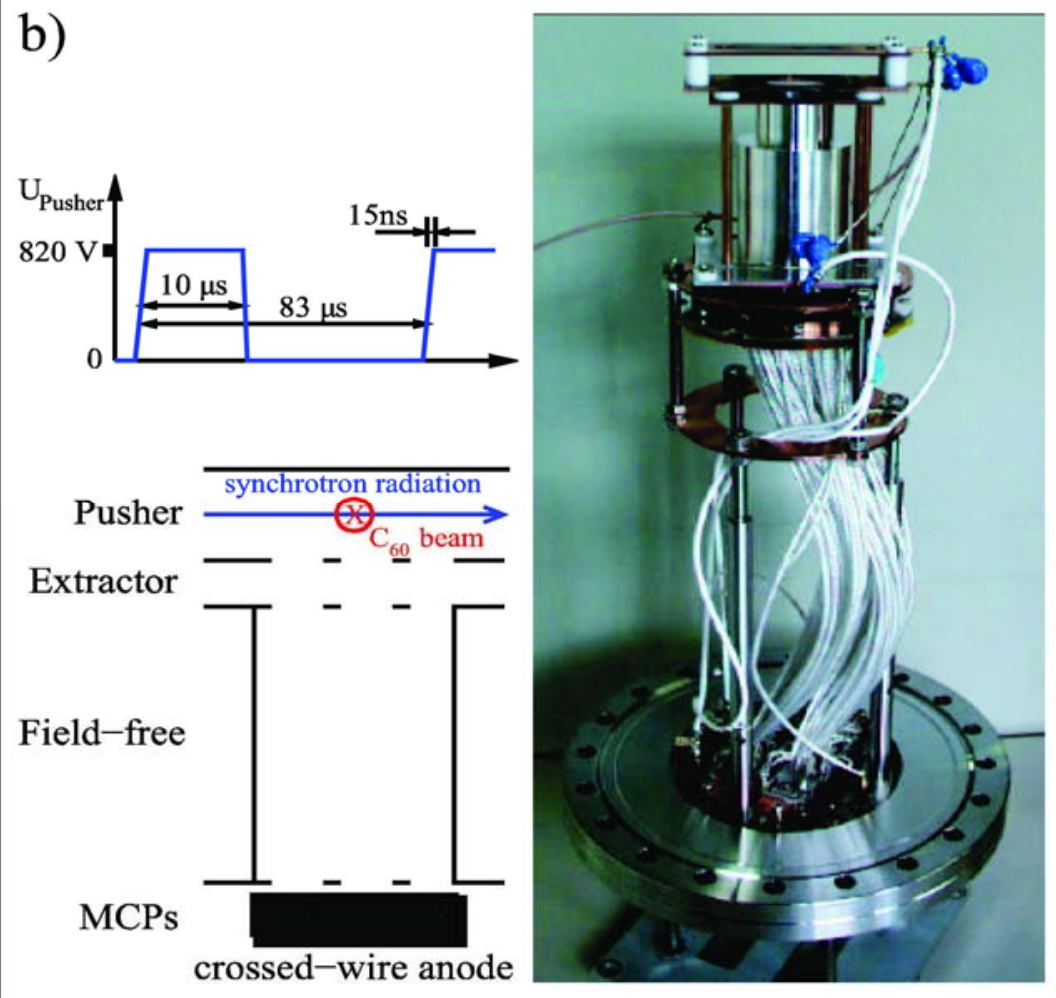

Figure 1 - Sketch of the experimental set-up. (a)beam source with the electron time-offlight (TOF) spectrometer. (b)schematic view and picture of the ion spectrometer

Puc. 1 - Изображение экспериментального устройства (а)источник света с TOF спектрометром. (б) ионный спектрометр

Слика 1 - Приказ експерименталног уређаја: (а) извор снопа са TOF спектрометром, (б) јонски спектрометар 


\section{Results and discussion}

\section{Inner shell ionization and fragmentation of $C_{60}$ molecule}

Figure 2 shows an example of the ion spectrum recorded at the photon energy of $390 \mathrm{eV}$. The inset shows the low-mass region of the spectrum. A rough classification of different processes is indicated by different coloured areas. In these processes, $\mathrm{C}^{q^{+}}{ }_{60}$ ions with charge states up to $3+$ and several smaller $\mathrm{C}^{q^{+}} 60-2 \mathrm{~m}$ fragments have been observed. This is in accordance with the previous claim that the main fragmentation channel is the emission of neutral $C_{2}$. Large singly charged carbon clusters (such as $\mathrm{C}_{30}^{+}, \mathrm{C}^{+}{ }_{29}$, or $\mathrm{C}^{+}{ }_{20}$ ) have no particular stability and one ought to expect additional species with similar sizes (such as $\mathrm{C}_{31}^{+}$or $\mathrm{C}^{+}{ }_{21}$ ), which have not been observed. For all photon energies used, no small charged carbon fragments resulting from fission or multifragmentation processes are observed.

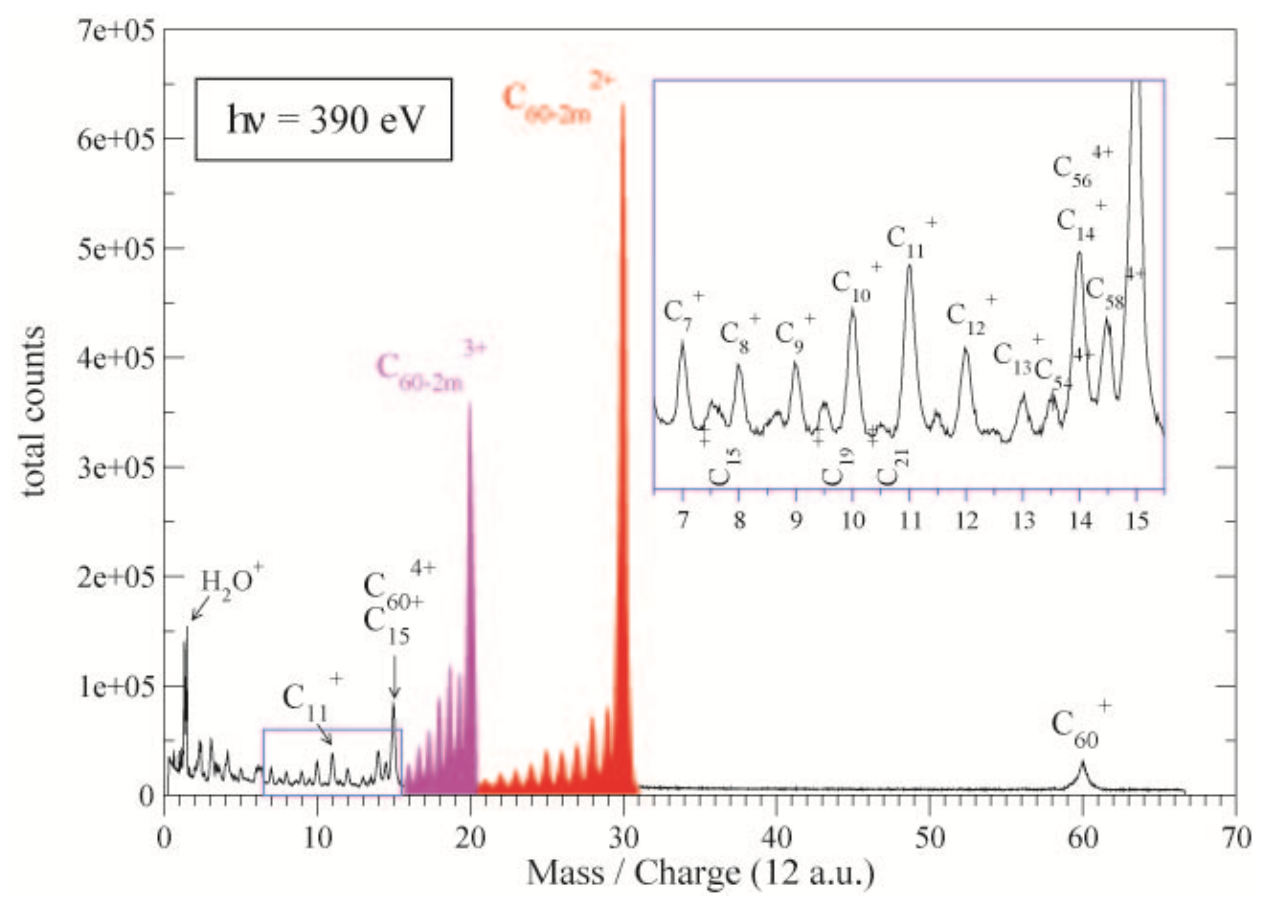

Figure 2 - Ion spectrum recorded with a photon energy of $390 \mathrm{eV}$

Puc. 2 - Ионный спектр, записанный на энергии фотона $390 \mathrm{eV}$

Слика 2 - Јонски спектар снимљен на енергији фотона од 390 eV 


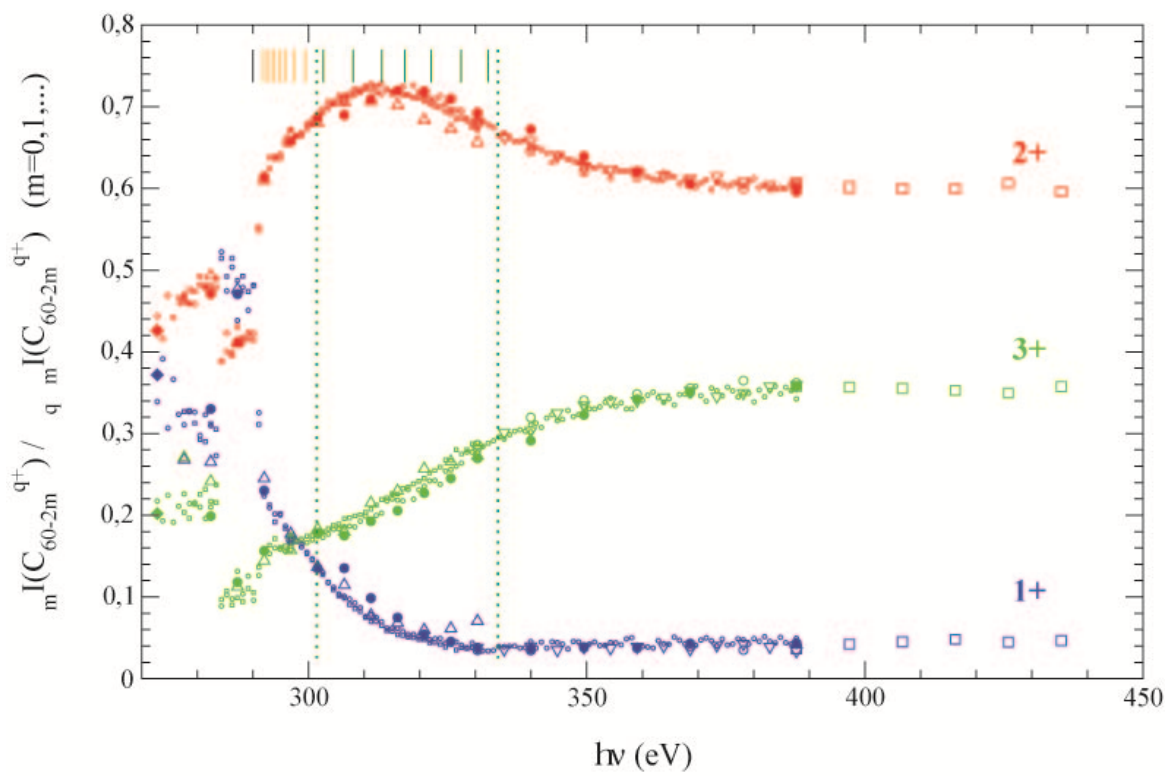

Figure 3 - Contributions of singly, doubly, and triply charged fullerene ions for several photon energies. Different scans are marked by different symbols. The results of the coincident electron spectrum are marked by ' $e$ '. The vertical lines indicate the $C(1 \mathrm{~s})$ threshold $(\Delta)$, electron shake-up levels $(\Delta)$, and plasmon excitation energies $(\Delta)$ (Leiro et al, 2003, pp.205-213). The high amount of triply charged fullerene can be explained by double Auger and electron shake-off processes, observed in the electron-electroncoincidence map (Fig.4).

Pис. 3 - Вклад однозарядных, двухзарядных и трехзарядных ионов фруллерена по нескольким значениям энергии фотонов. Разные сканы отмечены различными символами. Результаты совпадающего электронного спектра обозначены «е». Вертикальные линии обозначают C (1s) порог ( $\Delta)$, электронные уровни sheik-up

$(\Delta)$ и энергию возбуждения плазмы (L) (Leiro et al, 2003, pp. 205-213). Высокий процент трехзарядных фруллеренов можно объяснить двойными Оже- прочессом и электронным sheik-uр процессом, которые видны на карте совпадений электронов (рис.4).

Слика 3 - Доприноси једноструко, двоструко и троструко наелектрисаних јона фуллерена за неколико вредности енергије фотона. Различити скенови су означени различитим симболима. Резултати коинцидентног електронског спектра означени су са 'e' . Вертикалне линије означавају $C(1 \mathrm{~s})$ границу ( $\Delta)$, електронске шејк-ап нивое $(\Delta)$ и енергије плазмонских ексцитација ( $\triangle$ ) (Leiro et al, 2003, pp.205-213). Висок проценат троструко наелектрисаних фулерена може се објаснити двоструким Ожеовим и електронским шејк-оф процесима, који се могу видети на електрон-електрон коинцидентној мапи (слика 4). 
Figure 3 shows contributions of singly, doubly and triply charged fullerene ions for several photon energies. These results indicate that, above the carbon $\mathrm{K}$-shell of $\mathrm{C}_{60}$, the main products are doubly and triply charged fullerenes. $\mathrm{C}_{60}^{+}$is the most abundant ion in the low energy region. The relative $\mathrm{C}^{2+}{ }_{60}$ yield compared to the $\mathrm{C}_{60}^{+}$yield first increases with increasing photon energy and stagnates above $\approx 350 \mathrm{eV}$ at a nearly constant level. The yield of triply charged $\mathrm{C}^{3+}{ }_{60}$ is similar to the yield of $\mathrm{C}^{2+}{ }_{58}$. Different doubly charged $\mathrm{C}^{2+}{ }_{60-2 m}$ fragments appear step by step with increasing photon energy. The yields of singly charged fragments exhibit an enhancement in certain photon energy regions; at high photon energies, these yields decrease and are only slightly visible.

So the obtained ion yield spectroscopy of gas phase $\mathrm{C}_{60}$ is corroborated by the corresponding photoelectron measurements (Korica et al, 2018). The continuous intensity distribution in the photoelectron spectra can be either the result of direct double photoionization or double-Auger decay. The quality of the former K-shell photoelectron measurements was insufficient to disentangle these two contributions experimentally (Aksela et al, 1995, pp.2112-2115), (LeBrun et al, 1994, pp.3965-3968), (Brühwiler et al, 1993, pp.3721-3724), (Krummacher et al, 1993, pp.8424-8429). In general, the disentanglement of the two processes on the basis of normal ion or electron spectroscopy is not unambiguously possible.

\section{Electron-electron coincidence spectroscopy of excited $C_{60}$}

Electron-electron-coincidence measurements were carried out to get a deeper understanding about the fundamental processes causing the many-electron emission in $\mathrm{C}_{60}$. Here, a separation of different underlying processes can be better achieved. (Fig. 4).

Shake-off electrons are abundant at low-kinetic energies. Therefore, even at such high photon energies, shake-off processes are important to understand the yields of the multiply charged $\mathrm{C}_{60}$ ions besides the Auger and double Auger processes. In the case that two shake-off electrons leave the $\mathrm{C}_{60}$ molecule, the energy sharing is very asymmetric. The faster of the two shake-off electrons contributes signifcantly to the broad peak besides the $\mathrm{C}(1 \mathrm{~s})$ main line, usually referred to as the 'plasmon' peak (Hertel et al, 1992, pp.784-787), (Leiro et al, 2003, pp.205-213); this possibility has been unrevealed so far. 


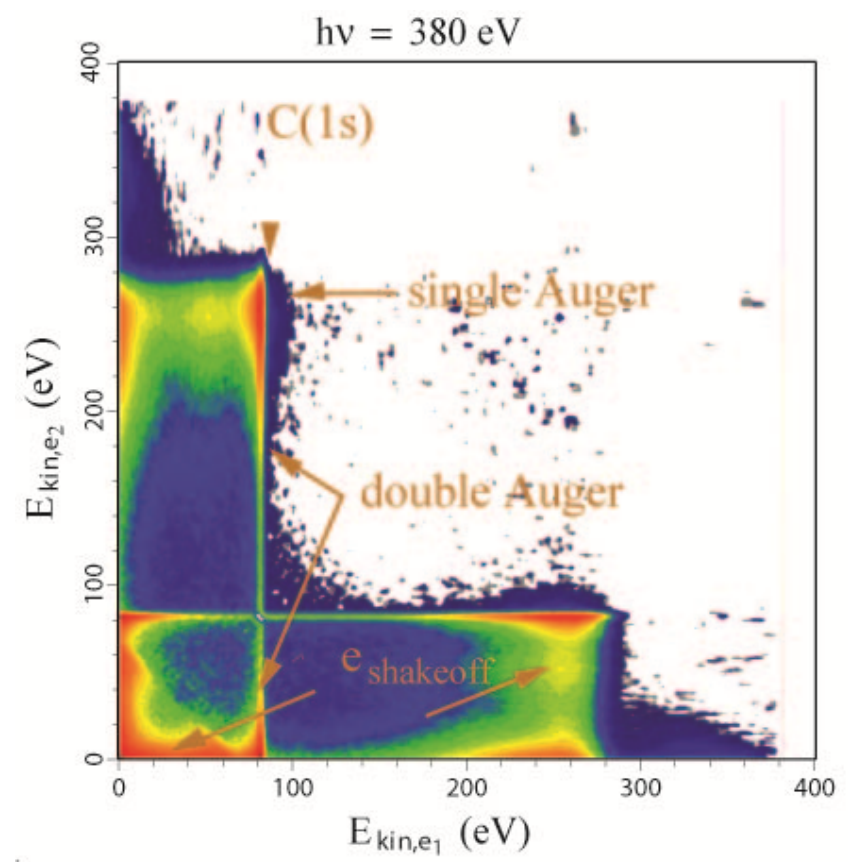

Figure 4 - Electron-electron coincidences as a function of the kinetic energy of the two detected electrons. The coincidence map was recorded with a photon energy of $380 \mathrm{eV}$. Puc. 4 - Карта совпадений электронов как функция кинетической энергии двух обнаруженных электронов. Карта совпадений записана на нергии фоотона 380 eV. Слика 4 - Електрон-електрон коинциденце као фрункција кинетичке енергије два детектована електрона. Коинцидентна мапа снимљена је на енергији фотона од $380 \mathrm{eV}$.

\section{Conclusion}

We have studied the photoionization of the $\mathrm{C}_{60}$ molecule above the $\mathrm{C}(1 \mathrm{~s})$ threshold, in the photon energy range $\mathrm{hv}=(330-390) \mathrm{eV}$. A careful analysis of the spectra yielded a surprising and unexpected result.

Clear hints have been found that the major contribution to the triply charged ion yield is the direct double photoionization of $\mathrm{C}_{60}$. However, in contrast to most atoms and molecules, it is driven by the plasmon excitation associated with the K-shell photoionization of the fullerenes. Whereas the K-shell satellites are still bound core excited ionic states of the $\mathrm{C}_{60}$ molecule, plasmon excitations at higher binding energies are already in the double electron emission continuum. This causes a specific intensity distribution and explains the origin of the broad resonance features in the continuum part of the spectrum and an unusual high amount of triply charged fullerenes of $40 \%$. 


\section{References}

Aksela, S., Nõmmiste, E., Jauhiainen, J., Kukk, E., Karvonen, J., Berry, H.G., Sorensen, S.L. \& Aksela, H. 1995. Photofragmentation of $\mathrm{C}_{60}$ Molecules following Resonance Excitation and Ionization near the C 1s Edge. Physical Review Letters, 75(11), pp.2112-2115. Available at: https://doi.org/10.1103/physrevlett.75.2112.

Bernard, J., Martin, S., Chen, L., Cederquist, H., Salmoun, A., \& Brédy, R. 2003. A single ion $(A r q+q=1,3$ or $C 603+)$ in a conic electrode electrostatic trap. Nuclear Instruments and Methods in Physics Research Section B: Beam Interactions with Materials and Atoms, 205, pp.196-200. Available at: https://doi.org/10.1016/s0168-583x(03)00553-6.

Brühwiler, P.A., Maxwell, A.J., Rudolf, P., Gutleben, C.D., Wästberg, B., \& Mårtensson, N. 1993. C1s autoionization study of electron hopping rates in solid $\mathrm{C}_{60}$. Physical Review Letters, 71(22), pp.3721-3724. Available at: https://doi.org/10.1103/physrevlett.71.3721.

Hertel, I.V., Steger, H., de Vries, J., Weisser, B., Menzel, C., Kamke, B., \& Kamke, W. 1992. Giant plasmon excitation in free $\mathrm{C}_{60}$ and $\mathrm{C} 70$ molecules studied by photoionization. Physical Review Letters, 68(6), pp.784-787. Available at: https://doi.org/10.1103/physrevlett.68.784.

Karvonen, J., Nõmmiste, E., Aksela, H., \& Aksela, S. 1997. Photoion spectra of $\mathrm{C}_{60}$ molecules at resonance excitation and ionization energies near the $C$ 1s edge. Journal of Chemical Physics, 106(9), pp.3466-3472. Available at: https://doi.org/10.1063/1.473442.

Korica, S., Reinköster, A., \& Becker, U. 2018. Strong enhancement of double Auger decay following Plasmon excitation in $\mathrm{C}_{60}$. Vojnotehnički glasnik/Military Technical Courier, 66(3), pp.483-494. Available at: https://doi.org/10.5937/vojtehg66-16269.

Korica, S., Rolles, D., Reinköster, A., Langer, B., Viefhaus, J., Cvejanović, S., \& Becker, U. 2005. Partial cross sections and angular distributions of resonant and nonresonant valence photoemission of $\mathrm{C}_{60}$. Physical Review $A$, 71(1), pp.132031-132035.

Available

at: https://doi.org/10.1103/physreva.71.013203.

Krätschmer, W., Lamb, L.D., Fostiropoulos, K., \& Huffman, D.R. 1990. Solid $\mathrm{C}_{60}$ : a new form of carbon. Nature, 347(6291), pp.354-358. Available at: https://doi.org/10.1038/347354a0.

Kroto, H.W., Heath, J.R., O'Brien, S.C., Curl, R.F., \& Smalley, R.E. 1985. $\mathrm{C}_{60}$ : Buckminsterfullerene. Nature, 318(6042), pp.162-163. Available at: https://doi.org/10.1038/318162a0.

Krummacher, S., Biermann, M., Neeb, M., Liebsch, A., \& Eberhardt, W. 1993. Close similarity of the electronic structure and electron correlation in gasphase and solid $\mathrm{C}_{60}$. Physical Review B, 48(11), pp.8424-8429. Available at: https://doi.org/10.1103/physrevb.48.8424. 
Kusmany, H., Fink, J., Mehring, M., \& Roth, S. 1993. Electronic Properties of Fullerenes. In Springer Series in Solid-State Sciences. Berlin: Springer. Vol. 177.

LeBrun, T., Berry, H.G., Cheng, S., Dunford, R.W., Esbensen, H., Gemmell, D.S., Kanter, E.P., \& Bauer, W. 1994. Ionization and Multifragmentation of $\mathrm{C}_{60}$ by High-Energy, Highly Charged Xe lons. Physical Review Letters, 72(25), pp.3965-3968. Available at: https://doi.org/10.1103/physrevlett.72.3965.

Leiro, J.A., Heinonen, M.H., Laiho, T., \& Batirev, I.G. 2003. Core-level XPS spectra of fullerene, highly oriented pyrolitic graphite, and glassy carbon. Journal of Electron Spectroscopy and Related Phenomena, 128(2-3), pp.205-213. Available at: https://doi.org/10.1016/s0368-2048(02)00284-0.

Lykke, K.R. 1995. Fragmentation of $\mathrm{C}_{60}$ : Experimental detection of $\mathrm{C}, \mathrm{C}_{2}$, $\mathrm{C}_{3}$, and $\mathrm{C}_{4}$ by xuv postionization. Physical Review A, 52(2), pp.1354-1357. Available at: https://doi.org/10.1103/physreva.52.1354.

Reinköster, A., Siegmann, B., Werner, U., \& Lutz, H.O. 2003. Ion-impact induced excitation and fragmentation of $\mathrm{C}_{60}$. Radiation Physics and Chemistry, 68(1-2), pp.263-267. Available at: https://doi.org/10.1016/s0969-806x(03)002950 .

Scheier, P., Dünser, B., Wörgötter, R., Lezius, M., Robl, R., \& Märk, T.D. 1994. Appearance and ionization energies of singly, doubly and triply charged $\mathrm{C}_{60}$ and its fragment ions produced by electron impact ionization. International Journal of Mass Spectrometry and Ion Processes, 138, pp.77-93. Available at: https://doi.org/10.1016/0168-1176(94)04034-6.

\section{ИССЛЕДОВАНИЕ ДВОЙНОЙ ЭЛЕКТРОННОЙ ЭМИССИИ,} СВЯЗАННОЙ С ФОТОИОНИЗАЦИЕЙ К-ОБОЛОЧКИ С 60

Саня Л. Корица ${ }^{a}$, Аксел Райнкостер ${ }^{б}$, ве Бекер $^{B}$

" Университет «Унион - Никола Тесла», Факультет экологии и охраны окружающей среды, г. Белград, Республика Сербия + Институт им. Фрица Габера, Отделение молекулярной фризики, г. Берлин, Федеративная Республика Германия

${ }^{\sigma}$ Институт им. Фрица Габера, Отделение молекулярной фризики, г. Берлин, Федеративная Республика Германия

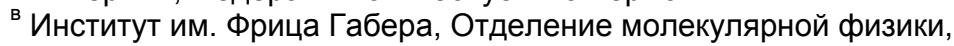
г. Берлин, Федеративная Республика Германия

ОБЛАСТЬ: молекуларная фризика, фотоэлектрон-фотоионная спектроскопия

ВИД СТАТЬИ: оригинальная научная статья

ЯЗЫК СТАТЬИ: английский

Резюме:

(Многогранная) фотоионизация и сопроводительная фрагментация молекулы $C_{60}$ исследовалась $c$ помощью синхротронного излучения после выброса электрона из 
внутренней К-оболочки. Наше исследование было сосредоточено на динамике сопроводительной фррагментации. Кроме «нормальной» (несовпадающей) электронной и ионной спектроскопии, применялись и друаие методы измерений, так например, было проведено измерение электронного совпадения. Наш эксперимент показал, что в течение этих процессов формируются $\mathrm{C}_{60}^{q+}$ ионы $\mathrm{c}$ зарядом до трех + u несколько небольших $\mathrm{C}^{q+}{ }_{60-2 m}$ фррагментов. Кроме того, был выявлен широкий пик рядом с основной линией $C$ (1s), так называемым «плазмоном».

Ключевые слова: молекулярная фризика, фотоелектронфотоионная спектроскопия, возбуждение плазмона.

КОИНЦИДЕНТНА СТУДИЈА ДВОСТРУКЕ ЕЛЕКТРОНСКЕ ЕМИСИЈЕ ПОВЕЗАНЕ СА ФОТОЈОНИЗАЦИЈОМ К-ЉУСКЕ С ${ }_{60}$

Сања Љ. Корица ${ }^{a}$, Аксел Рајнкостер ${ }^{6}$, Уве Бекер $^{B}$

а Универзитет Унион - Никола Тесла, Факултет за екологију и заштиту животне средине, Београд, Република Србија + Институт Фриц Хабер, Одсек за молекуларну физику, Берлин, Савезна Република Немачка

${ }^{\sigma}$ Институт Фриц Хабер, Одсек за молекуларну физику, Берлин, Савезна Република Немачка

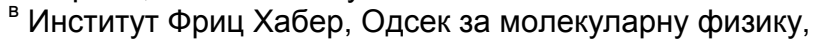
Берлин, Савезна Република Немачка

ОБЛАСТ молекуларна фризика, фротоелектронско-фотојонска спектроскопија

ВРСТА ЧЛАНКА: оригинални научни чланак

ЈЕЗИК ЧЛАНКА: енгЛескИ

\section{Сажетак:}

Фотојонизација (вишеструка) и пратећа фррагментација молекула $\mathrm{C}_{60}$ проучавана је уз помоћ синхротронског зрачења након избацивања електрона из унутрашње К-љуске. Наше истраживање било је посебно фоокусирано на динамику пратеће фррагментације. Поред „нормалне” (некоинцидентне) електронске и јонске ТОФ спектроскопије, ову тему изучавали смо и уз помоћ електрон-електрон коинцидентног мерења. Наш експеримент показује да се у овим процесима фоормирају $\mathrm{C}_{60}^{q+}$ јони са наелектрисањем до $3+$ и неколико мањих $C^{q^{+}}{ }_{60-2 m}$ фррагмената. Поред тога, поред главне C(1s) линије уочен је широки пик, тзв. плазмон.

Кључне речи: фризика молекула, фротоелектронска-фотојонска спектроскопија, плазмонска ексцитација. 
Paper received on / Дата получения работы / Датум пријема чланка: 11.02.2018. Manuscript corrections submitted on / Дата получения исправленной версии работы / Датум достављања исправки рукописа: 12.04.2018.

Paper accepted for publishing on / Дата окончательного согласования работы / Датум коначног прихватања чланка за објављивање: 14.04.2018.

(c) 2018 The Authors. Published by Vojnotehnički glasnik / Military Technical Courier

(www.vtg.mod.gov.rs, втг.мо.упр.срб). This article is an open access article distributed under the terms and conditions of the Creative Commons Attribution license (http://creativecommons.org/licenses/by/3.0/rs/).

() 2018 Авторы. Опубликовано в «Военно-технический вестник / Vojnotehnički glasnik / Military Technical Courier» (www.vtg.mod.gov.rs, втг.мо.упр.срб). Данная статья в открытом доступе и распространяется в соответствии с лицензией «Creative Commons» (http://creativecommons.org/licenses/by/3.0/rs/).

( 2018 Аутори. Објавио Војнотехнички гласник / Vojnotehnički glasnik / Military Technical Courier (www.vtg.mod.gov.rs, втг.мо.упр.срб). Ово је чланак отвореног приступа и дистрибуира се у складу са Creative Commons licencom (http://creativecommons.org/licenses/by/3.0/rs/). 